Yakin Niat

Telaumbanua $^{1}$

Pniel Sozawato

Zendrato $^{2}$

\section{ANALISIS PEMBELAJARAN MATEMATIKA DENGAN MENGGUNAKAN APLIKASI AUTOGRAPH}

\begin{abstract}
Abstrak
Penelitian ini bertujuan untuk menganalisis pembelajaran matematika dengan menggunakan aplikasi autograph. Pembelajaran dengan menggunakan aplikasi autograph merupakan pembelajaran yang dapat melibatkan visual dan keaktifan mahasiswa dalam belajar matematika. Pembelajaran dengan menggunakan autograph merupakan pembelajaran dengan memanfaatkan komputer sebagai salah satu alat bantu yang efektif dan efisien dalam menunjang kualitas pembelajaran. Aplikasi autograph adalah apalikasi yang mempelajari tentang dua dimensi, tiga dimensi, statistik, transformasi, geometri, persamaan, koordinat, differensial, grafik, serta aljabar. Metode yang digunakan dalam penelitian ini adalah kualitatif dengan analisis deskriptif. Penelitian ini dilaksanakan kepada mahasiswa Program Studi Pendidikan Matematika, Fakultas Pendidikan Matematika dan Ilmu Pengetahuan Alam (FPMIPA) IKIP Gunungsitoli. Berdasarkan hasil penelitian, diperoleh bahwa : 1) Aplikasi autograph merupakan aplikasi yang mudah dimiliki oleh mahasiswa, 2) Aplikasi autograph mudah dipelajari oleh mahasiswa, 3) Pembelajaran menjadi lebih menarik dan menyenangkan bagi mahasiswa dengan menggunakan autograph, 4) Mahasiswa menjadi termotivasi untuk belajar, 5) Mahasiswa dapat menggambar grafik dan bentuk geometri dengan lebih cepat, mudah dan menarik.
\end{abstract}

Kata Kunci: Pembelajaran Matematika, Autograph.

\title{
Abstract
}

This research aims to analyze mathematics learning by using an autograph application. Learning by using the autograph application is learning that can involve visual and student activity in learning mathematics. Learning by using autograph is learning by using a computer as an effective and efficient tool in supporting the quality of learning. Autograph application is an application that studies about two dimensions, three dimensions, statistics, transformation, geometry, equations, coordinates, differential, graphs, and algebra. The method used in this research is qualitative with descriptive analysis. This research was conducted to students of Program Studi Pendidikan Matematika, Fakultas Pendidikan Matematika dan Ilmu Pengetahuan Alam (FPMIPA) IKIP Gunungsitoli. Based on the research results, it was found that: 1) The autograph application is an application that is easily owned by students, 2) The autograph application is easy to learn by students, 3) Learning becomes more interesting and enjoyable for students by using autographs, 4) Students become motivated to learn, 5) Students can draw graphs and geometric shapes faster, easier and more interesting.

Keywords: mathematics learning, autograph.

\footnotetext{
${ }^{1}$ Prodi Pendidikan Matematika, FPMIPA IKIP Gunungsitoli

Alamat email: telaumbanua.yakin@yahoo.com

${ }^{2}$ Prodi Bahasa Indonesia, IKIP Gunungsitoli
} 


\section{PENDAHULUAN}

Belajar adalah suatu kegiatan yang dilakukan untuk memperoleh pengetahuan dan keterampilan yang bermanfaat bagi kehidupan orang itu sendiri dan orang banyak. Menurut Sagala (2011:12) bahwa untuk memperoleh pengetahuan, perilaku dan keterampilan dalam proses pembelajaran adalah dengan cara mengolah bahan ajar. Selanjutnya menurut Cronbach (Hosnan, 2013:3), "learning is shown by a change in behavior as a result of experience”. Maksudnya adalah dengan belajar perubahan perilaku dapat terjadi sebagai hasil dari pengalaman.

Ketika belajar matematika, peserta didik (mahasiswa) kadang mengalami kesulitan dalam mengolah informasi dan pengetahuan yang diterima. Sehingga informasi dan pengetahuan dapat terlewat begitu saja tanpa dipahami oleh mahasiswa. Hal tersebut terjadi, dikarenakan dalam mendapatkan informasi mahasiswa tidak dilibatkan secara visual dan mahasiswa tidak langsung terlibat aktif. Salah satu yang dapat melibatkan visual dan keaktifan mahasiswa ketika belajar matematika, yaitu dengan menggunakan teknologi seperti komputer dengan aplikasi yang menarik untuk digunakan.

Menurut Hasibuan (2016), salah satu alat bantu yang efektif dan efisien dalam pemanfaatan komputer dalam menunjang kualitas pembelajaran adalah dengan menggunakan autograph. Menurutnya aplikasi autograph adalah aplikasi yang mempelajari tentang dua dimensi, tiga dimensi, statistik, transformasi, geometri, persamaan, koordinat, differensial, grafik, aljabar.

Menurut Ghozi1 \& Hilmansyah (2018) bahwa aplikasi autograph memberikan kontribusi dalam meningkatkan motivasi mahasiswa dalam belajar matematika. Selanjutnya, Ghozi1 \& Hilmansyah mengatakan bahwa autograph ini sangat bagus dalam visualisasi geometri, karna memiliki kemampuan grafik 2D dan 3D untuk topiktopik seperti transformasi, kerucut bagian, vektor, kemiringan, aplikasi integral dan turunan. Pengguna dapat mengamati bagaimana fungsi, grafik, persamaan, dan perhitungan (Zagoto, dkk., 2018; Sarumaha, 2018; Dakhi, O., 2013).

Pembelajaran dengan menggunakan aplikasi autograph lebih efektif jika dibandingkan dengan pembelajaran konvensial. Hal ini sejalan dengan hasil penelitian yang dilakukan oleh Buchori (2010) bahwa pembelajaran menggunakan autograph lebih efektif dibandingkan dengan pembelajaran konvensional. Berdasarkan uraian-uraian tersebut, maka peneliti melakukan penelitian dengan menganalisis pembelajaran matematika dengan menggunakan aplikasi autograph (Zagoto \& Nevy, 2018; Dakhi, O., 2013) 


\section{METODE}

\section{Metode Penelitian}

Pembelajaran matematika dengan menggunakan aplikasi autograph dalam penelitian ini dilakukan kepada mahasiswa Program Studi Pendidikan Matematika, FPMIPA IKIP Gunungsitoli. Metode yang digunakan dalam penelitian ini adalah metode dengan menggunakan pendekatan kualitatif dengan analisis deskriptif.

Penelitian deskriptif menurut Arikunto (Prabowo \& Heriyanto, 2013) adalah Penelitian yang mengumpulkan data berdasarkan faktor- faktor pendukung terhadap objek penelitian, kemudian faktor- faktor tersebut dianalisa untuk dicari peranannya. Selanjutnya (Prabowo \& Heriyanto, 2013) mengatakan bahwa penelitian kualitatif merupakan penelitian yang berkaitan dengan ide, persepsi, pendapat, kepercayaan orang yang akan diteliti dan tidak dapat di ukur dengan angka. Jadi, penelitian deskriptif kualitatif adalah penelitian dengan pengolahan data dengan cara menganalisa faktorfaktor yang berkaitan dengan objek penelitian dengan kemudian menganalisanya secara lebih mendalam. Pengolahan data dilakukan dengan triangulasi (pemeriksaan keabsahan data), reduksi (merangkum hal-hal yang penting), penyajian data (bentuk naratif) dan penarikan kesimpulan.

\section{Pengumpulan Data}

Data dalam penelitian ini diperoleh dengan cara melakukan observasi dan wawancara kepada mahasiswa ketika pembelajaran sedang berlangsung dan setelah selesai pembelajaran.

\section{Analisis Data}

Untuk mendapatkan jawaban atas masalah penelitian, yakni menganalisa pembelajaran matematika dengan menggunakan aplikasi autograph, maka data yang telah diperoleh dalam penelitian ini dianalisis dengan cara mencari hubungan data yang diperoleh dengan objek-objek penelitian dan kemudian mendeskripsikannya. Data yang telah dianalisis tersebut kemudian ditarik kesimpulannya dan dideskripsikan dengan jelas.

Data yang dihasilkan dari observasi dianalisis dengan melihat bagaimana keaktifan mahasiswa selama proses pembelajaran dan bagaimana kemampuan mahasiswa saat menggunakan aplikasi autograph.

Demikian juga halnya dengan hasil wawancara. Data hasil wawancara dianalisis berdasarkan jawaban-jawaban dari mahasiswa. Dari jawaban-jawaban siswa bisa diperoleh informasi tentang apa yang dirasakan mahasiswa serta bagaimana proses pembelajaran dengan menggunakan aplikasi autograph.

\section{HASIL DAN PEMBAHASAN}

Peneliti mengumpulkan data penelitian melalui observasi dan wawancara dengan melaksanaan pembelajaran matematika dengan menggunakan aplikasi 
autograph yang dilakukan oleh peneliti. Pada penelitian ini, pembelajaran dilaksanakan dengan menggunakan aplikasi autograph.

Deskripsi pembelajaran yang dilakukan dengan menggunakan autograph yaitu, pembelajaran dimulai dengan memperkenalkan aplikasi autograph kepada mahasiswa. Peneliti menyampaikan kepada mahasiswa bahwa manfaat aplikasi autograph adalah untuk mempelajari dan memvisualisasikan suatu bangun dalam bentuk dua dimensi, tiga dimensi, statistik, transformasi, geometri, persamaan, koordinat, differensial, grafik, aljabar dan sebagainya. Selanjutnya disampaikan bahwa aplikasi autograph dapat didownload dari internet dengan situs http://www.autograph-maths.com/download/cy/.

Setelah aplikasi autograph diperkenalkan kepada mahasiswa, peneliti menggunakan aplikasi autograph dengan mengambarkan bentuk dua dimensi suatu bangun, tiga dimensi, dan bentuk geometri lainnya serta bentuk persamaan garis dan sebagainya. Dalam mengambarkan bangun berbentuk dua dimensi, tiga dimensi, dan bentuk geometri lainnya, mahasiswa menjadi lebih fokus dan tertarik dalam memperhatikan setiap gambar muncul dalam aplikasi tersebut. Hal ini disebabkan aplikasi autograph merupakan hal yang baru diperkenalkan kepada mahasiswa dan sangat membantu dalam mengambar atau memvisualisasikan sesuatu dengan lebih mudah, cepat, bervariasi dan menarik.

Dari pengamatan peneliti, tampak bahwa mahasiswa menjadi lebih antusias dalam pembelajaran. Hal ini dibuktikan dengan pertanyaan-pertanyaan refleks yang disampaikan mahasiswa. Mahasiswa menjadi penasaran bagaimana suatu proses menghasilkan gambar yang menarik dan sangat cepat. Peneliti juga menjelaskan bagaimana cara mengambar grafik, bentuk dua dimensi, tiga dimensi dan bentuk geometri.

Setelah peneliti menjelaskan tentang aplikasi autograph, mahasiswa kemudian mendownload aplikasi autograph dan setelah itu menginstal di laptop masing-masing. Setelah berhasil diinstal, mahasiswa mencoba menggambar berbagai bentuk grafik, geometri dan bentuk lainnya di autograph. Mahasiswa dengan lebih mudah, cepat dan menarik menggambar berbagai bentuk di autograph jika dibandingkan secara manual, akan membutuhkan waktu yang lebih lama.

Setelah pembelajaran selesai dilaksanakan, observasi dan wawancara menjadi dasar dalam menjawab masalah penelitian yakni menganalisa pembelajaran matematika dengan menggunakan aplikasi autograph. Dalam menganalisa penelitian ini, ada beberapa hal yang perlu dianalisa oleh peneliti, yaitu:

a. Kemudahan mengakses autograph

b. Kemampuan mahasiswa dalam menggunakan autograph

c. Motivasi belajar mahasiswa

d. Manfaat aplikasi autograph

Berdasarkan penelitian yang dilakukan maka ada beberapa hal yang bisa diperoleh dalam pembelajaran matematika dengan menggunakan autograph yang diuraikan di bawah ini. 


\section{Hasil Observasi Penelitian}

Berdasarkan observasi penelitian yang dilakukan selama proses pembelajaran matematika maka diperoleh beberapa hasil penelitian, yaitu:

a. Kemudahan mengakses autograph

Dari hasil analisa diperoleh bahwa aplikasi autograph dapat dengan mudah diakses dan dimiliki oleh siswa. Mahasiswa mendapatkan aplikasi dengan mudah dengan mendownload aplikasinya di internet dan kemudian menginstalnya di komputer atau laptop masing-masing.

b. Kemampuan mahasiswa dalam menggunakan autograph

Berdasarkan hasil observasi yang dilakukan ketika proses pembelajaran matematika berlangsung, mahasiswa dengan mudah menggunakan autograph setelah penjelasan tentang cara menggunakan aplikasi yang disampaikan pengajar. Mahasiswa juga dapat dengan lebih mudah belajar dengan hasil yang lebih bervariasi karena cara menggunakan aplikasi autograph dapat ditemukan dari berbagai sumber dari internet. Jadi berdasarkan analisa diperoleh bahwa autograph mudah dipelajari oleh mahasiswa

c. Motivasi belajar mahasiswa

Mahasiswa menjadi lebih termotivasi dalam belajar dengan menggunakan aplikasi autograph dan dengan mudah menyelesaikan masalah-masalh yang ada dalam pembelajaran matematika. Hal ini disebabkan karena pembelajaran lebih menarik, melibatkan visual serta dapat langsung dipraktekkan dalam menggunakannya. Berdasarkan hasil analisa, maka motivasi belajar mahasiswa lebih tinggi.

\section{Hasil Wawancara}

Berdasarkan wawancara yang dilakukan kepada mahasiswa diperoleh data bahwa:

a. Pembelajaran lebih menarik bagi mahasiswa dengan menggunakan aplikasi autograph

b. Aplikasi autograph dapat dipelajari dan digunakan oleh mahasiswa dengan mudah, ditambah dengan petunjuk penggunaan aplikasinya yang bisa diperoleh dari berbagai sumber dari internet.

c. Dapat menggambar grafik dan bentuk geometri dengan lebih cepat, menarik dan bervariasi serta dapat menyelesaikan masalah tentang dua dimensi, tiga dimensi, statistik, transformasi, geometri, persamaan, koordinat, differensial, grafik, aljabar

Berdasarkan analisa dari hasil wawancara tersebut, diperoleh bahwa pembelajaran matematika dengan menggunakan autograph lebih menarik, autograph mudah untuk digunakan dan dapat menggambar grafik dan bentuk geometri dengan lebih cepat, menarik dan bervariasi. 
Berikut gambar hasil pekerjaan dari beberapa orang mahasiswa dengan menggunakan aplikasi autograph.

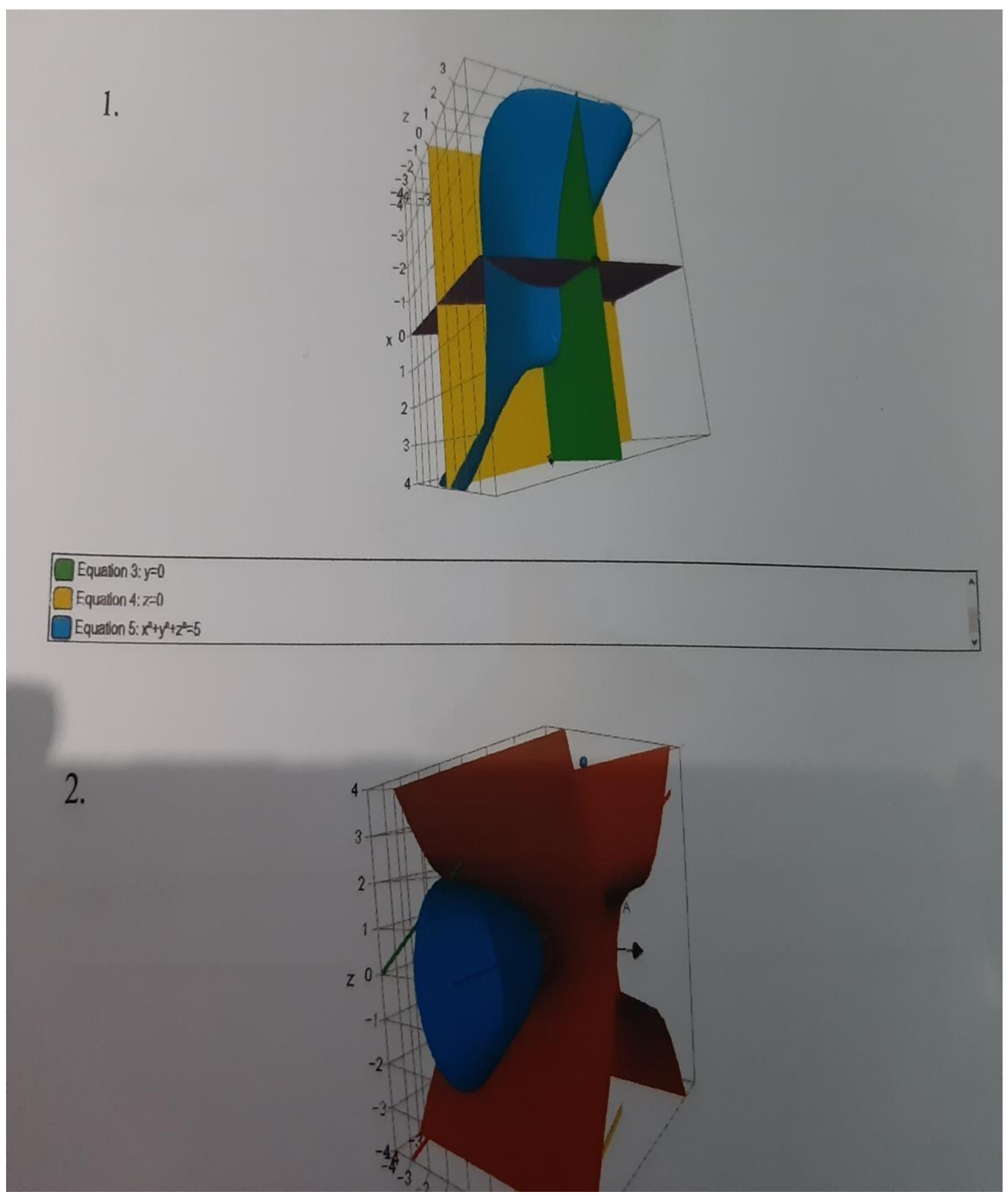

Gambar 1. Persamaan dan grafiknya (hasil autograph) 


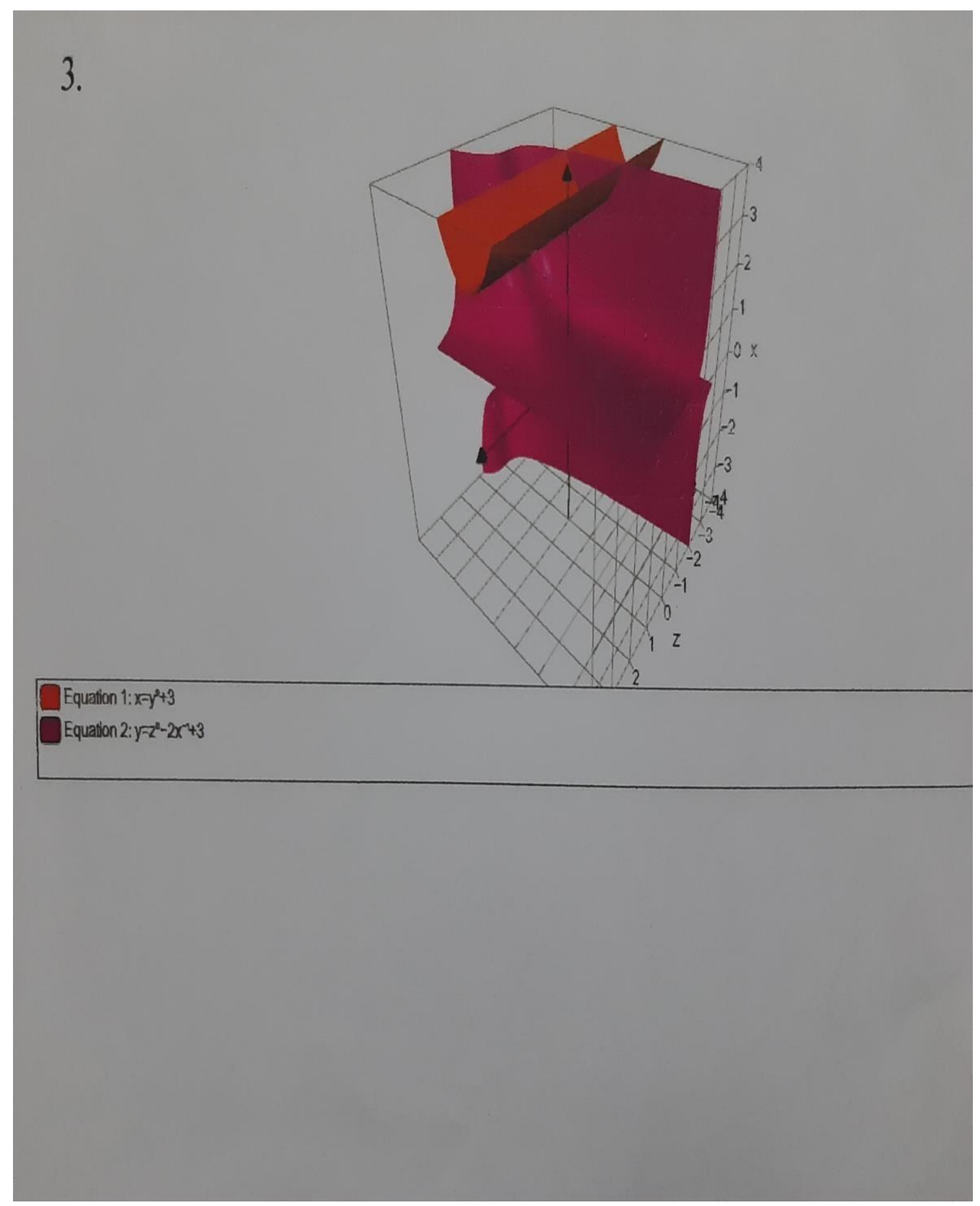

Gambar 2. Persamaan dan grafiknya (hasil autograph) 


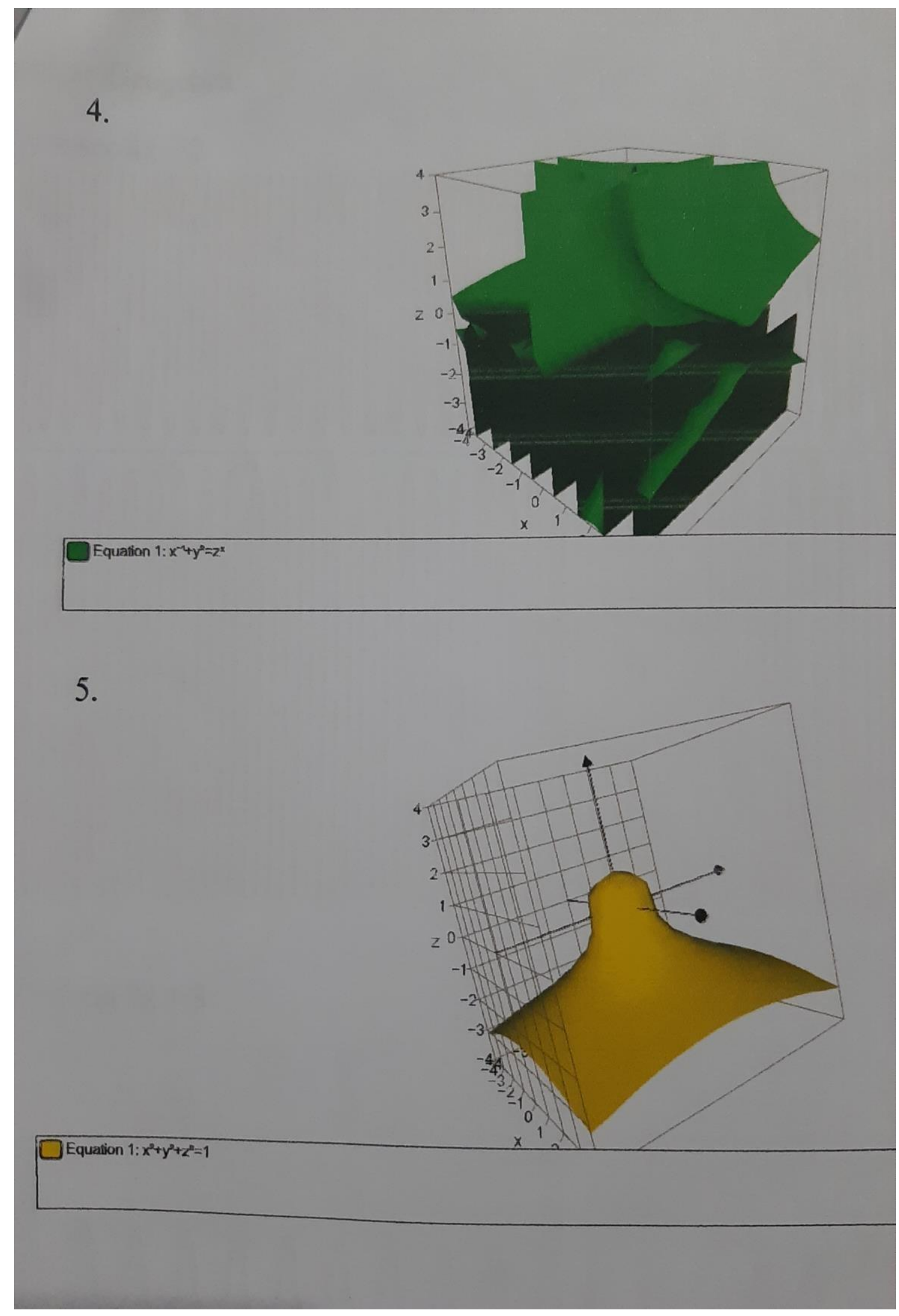

Gambar 3. Persamaan dan grafiknya (hasil autograph) 


\section{SIMPULAN}

Proses pembelajaran matematika dapat lebih menarik dan mudah diikuti oleh mahasiswa dengan bantuan aplikasi Autograph. Dalam Penelitian ini, terdapat beberapa kesimpulan dari hasil penelitian yaitu:

1. Aplikasi autograph merupakan aplikasi yang mudah dimiliki oleh mahasiswa

2. Aplikasi autograph mudah dipelajari oleh mahasiswa

3. Pembelajaran dengan menggunakan autograph menarik dan menyenangkan untuk dipelajari mahasiswa

4. Mahasiswa menjadi termotivasi untuk belajar

5. Mahasiswa dapat menggambar grafik dan bentuk geometri dengan lebih cepat, mudah dan menarik.

\section{DAFTAR PUSTAKA}

Buchori, Achmad. 2010. Keefektivan Penggunaan Autograph, Cabri 3d Dan Maple Sebagai Media Pembelajaran Matematika. AKSIOMA : Jurnal Matematika dan Pendidikan Matematika, 1(1).

Dakhi, O. "Aplikasi Pendeteksian Kerusakan File Akibat Virus Dengan Menggunakan Metode Heuristic." Pelita Informatika Budi Darma, vol. 4, no. 1, pp. 35-41, 2013.

Dakhi, O. 2013. Belajar Javascript Dengan Mudah Dan Detail. Jakarta: Dapur Buku. pp. 1-202. Ghozil \& Hilmansyah. 2018. Visualisasi Geometris Aplikasi Integral: Studi Penggunaan Software Autograph Dalam Pembelajaran Matematika Teknik. JNPM (Jurnal Nasional Pendidikan Matematika), 2 (1).

Hasibuan, Nailul Himmi. 2016. Pemanfaatan Autograph Sebagai Media Pembelajaran Matematika Dengan Menerapkan Model Pembelajaran Berbasis Masalah (PBM). Cahaya Pendidikan, 2(1).

Hosnan, 2013. Pendekatan Saintifik dan Kontekstual dalam Pembelajaran Abad 21. Bogor: Graha Indonesia

Prabowo \&Heriyanto. 2013. Analisis Pemanfaatan Buku Elektronik ( E-Book ) Oleh Pemustaka Di Perpustakaan Sma Negeri 1 Semarang. Jurnal Ilmu Perpustakaan, 2(2).

Sagala, Syaiful. 2011. Konsep dan Makna Pembelajaran. Bandung : Alfabeta.

Sarumaha, R., Harefa, D., \& Zagoto, Maria M. (2018). Upaya Meningkatkan Kemampuan Pemahaman Konsep Geometri Transformasi Refleksi Siswa Kelas XII-IPA-B SMA Kampus Telukdalam Melalui Model Pembelajaran Discovery Learning Berbantuan Media Kertas Milimeter. Jurnal Education and development, Vol.6 No.1, 90-96. https://doi.org/10.37081/ed.v6i1.668

Zagoto, Maria M., Yarni, Nevi; Dakhi, O. (2019). Perbedaan Individu dari Gaya Belajarnya Serta Implikasinya Dalam Pembelajaran. Jurnal Review Pendidikan dan Pengajaran, 2(2), 259265.

Zagoto, Maria M. \& Dakhi, O (2018). Pengembangan Perangkat Pembelajaran Matematika Peminatan Berbasis Pendekatan Saintifik Untuk Siswa Kelas XI Sekolah Menengah Atas. Jurnal Review Pendidikan dan Pengajaran, 1(1), 157-170.

Zagoto, Maria M. (2018). Pengembangan Perangkat Pembelajaran Matematika Berbasis Realistic Mathematic Educations Untuk Siswa Kelas V Sekolah Dasar, Jurnal Education And Development, vol. 3, no. 1, p. 53, Feb. 2018. https://doi.org/10.37081/ed.v3i1.139 